\title{
A new section for and by public health practitioners and decision-makers
}

In this issue, the Journal's Editorial Board is launching a new section entitled "Innovations in Policy and Practice". As explained in detail in Hancock et al.'s invited commentary in this same issue, the new section is specifically designed with the information needs of public health practitioners and decisionmakers in mind. Our aim is to increase the Journal's relevance for public health practice and policy both as a source of inspiration for the development of programs and policy, and as a venue in which practitioners and decision-makers can share their experience. For the past year, a group of engaged public health practitioners and decision-makers assembled by Trevor Hancock have shared ideas and experience about how their needs for communicating their innovative practices and knowing about other practitioners' and decision-makers' innovations could be met. In addition, in a commissioned report, Victoria Barr reviewed how other journals in the field of public health go about opening their pages to practitioners.

The Editorial Board decided that our section on Innovations in Policy and Practice should be managed and subjected to peer review by prominent public health practitioners with a strong track record of innovative practice and communication; that contributions should come primarily from practitioners and decision-makers, with the possibility of researchers as co-authors but not as main authors; and that the format should suit the information needs of practitioners and decision-makers. We believe that the new section will meet these criteria, and are eager to receive submissions.

One of our goals in publishing public health innovations described and analyzed in a rigorous manner is to foster new partnerships between research teams and innovative public health organizations. The nascent fields of population health intervention research and public health systems and services research value the conduct of studies on programs, policies and interventions that are designed and implemented within the public health system. It is our hope that articles in this new section will trigger the curiosity of the Canadian public health research community.

To continue the more than 100-year tradition of excellence of the Canadian Journal of Public Health, the Editorial Board has identified three strategic priorities for the Journal's future developments. Our first priority is that the Journal become a must-read for and increase its relevance to the whole public health community in Canada, and this includes practitioners and decision-makers. Another priority is to increase the Journal's relevance to the global public health community. Finally, we want the Journal to attract and publish the best possible research in all of its forms to contribute to improving people's health in Canada and globally. The launch of the Innovations in Policy and Practice section is a concrete step in the pursuit of our first priority. We hope that readers and writers agree that this was the

\section{Une nouvelle rubrique par et pour les praticiens et les décideurs de la santé publique}

Dans ce numéro, le comité éditorial de la Revue lance une nouvelle rubrique intitulée "Innovations dans les politiques et les pratiques ». Comme l'expliquent en détail Hancock et coll. dans leur commentaire invité de ce même numéro, la nouvelle rubrique est spécifiquement pensée en fonction des besoins d'information des praticiens et des décideurs de la santé publique. Notre but : accroître la pertinence de la Revue en ce qui concerne la pratique et les politiques de santé publique, tant pour en faire une source d'inspiration pour l'élaboration des programmes et politiques qu'une tribune où praticiens et décideurs pourront partager leur expérience. Depuis un an, un groupe de praticiens et de décideurs engagés, réunis par Trevor Hancock, partagent leurs idées et leur expérience afin de trouver des moyens de communiquer leurs pratiques novatrices et de se renseigner sur les innovations de leurs collègues. En outre, dans un rapport commandé, Victoria Barr examine comment d'autres revues du domaine de la santé publique s'y prennent pour ouvrir leurs pages aux praticiens.

Le comité éditorial a décidé que la rubrique sur les Innovations dans les politiques et les pratiques devrait être gérée et évaluée par des praticiens de la santé publique réputés, possédant de solides antécédents en matière de pratiques novatrices et de communication; que les manuscrits devraient provenir principalement de praticiens et de décideurs, éventuellement avec des chercheurs comme coauteurs mais non comme auteurs principaux; et que la formule choisie devrait répondre aux besoins d'information des praticiens et des décideurs. Nous croyons que la nouvelle rubrique répondra à ces critères et nous avons hâte de recevoir des manuscrits.

L'un de nos objectifs, en publiant des innovations en santé publique rigoureusement décrites et analysées, est de favoriser de nouveaux partenariats entre les équipes de recherche et les organismes de santé publique novateurs. Deux domaines naissants, la recherche interventionnelle en santé des populations et la recherche sur les systèmes et services de santé publique, apprécient que l'on étudie les programmes, les politiques et les interventions conçus et mis en œuvre dans le système de santé publique. Nous espérons que les articles de notre nouvelle rubrique éveilleront la curiosité des chercheurs canadiens en santé publique.

Pour poursuivre la tradition d'excellence plus que centenaire de la Revue canadienne de santé publique, le comité éditorial a défini trois priorités stratégiques pour l'évolution future de la Revue. Notre première priorité est d'en faire une lecture incontournable et d'en accroître la pertinence pour toute la communauté de la santé publique du Canada, praticiens et décideurs compris. Une autre priorité est d'accroître sa pertinence pour la communauté de la santé publique mondiale. Enfin, nous voulons que la Revue attire et publie les meilleures recherches possibles, sous toutes leurs formes, afin de contribuer à améliorer la santé des gens au Canada et dans le monde. Le lancement de la rubrique des 
right thing to do and that we will soon be in a position to publish our first series of innovations in policy and practice.

Louise Potvin, PhD

Editor in Chief, CJPH

Université de Montréal

doi : 10.17269/CJPH.106.5367
Innovations dans les politiques et les pratiques est un pas en avant dans la poursuite de notre première priorité. Nous espérons que les lecteurs et les auteurs conviendront que c'était la bonne chose à faire, et que nous serons bientôt en mesure de publier notre première série d'innovations dans les politiques et les pratiques.

Louise Potvin, Ph.D.

Rédactrice en chef, RCSP

Université de Montréal

doi: $10.17269 / \mathrm{C} \mid \mathrm{PH} .106 .5367$ 